Original Research Paper

\title{
Study of Chemical Composition of Extract from Beta Vulgaris Seeds and its Cytotoxic Activity
}

\author{
${ }^{1}$ Aiman Konkabayeva, ${ }^{1}$ Margarita Ishmuratova, \\ ${ }^{1}$ Gulmira Tykezhanova, ${ }^{1}$ Aidana Yerubay and ${ }^{2}$ Yerlan Suleimen \\ ${ }^{1}$ Department of Physiology, E.A. Buketov Karaganda University, Karaganda, Kazakhstan \\ ${ }^{2}$ The Laboratory of Engineering Profile of NMR Spectroscopy, Sh. Ualikhanov Kokshetau University, \\ Kokshetau, Kazakhstan, Republican Collection of Microorganisms, Nur-Sultan, Kazakhstan
}

\author{
Article history \\ Received: 24-03-2021 \\ Revised: 15-04-2021 \\ Accepted: 26-04-2021 \\ Corresponding Author: \\ Aiman Konkabayeva \\ Department of Physiology, \\ E.A. Buketov Karaganda State \\ University, Karaganda, \\ Kazakhstan \\ Email: Aiman54@mail.ru
}

\begin{abstract}
Nowadays, a variety of plants is being investigated with the aim of developing new medicines with improved properties and expanding the range of efficient and safe preparations. Modern studies of representatives of the family Amaranthaceae (Beta vulgaris) have revealed medicinal properties in plants that were used previously only as food. Many medicinal properties are due to the presence of betalains and phenols in the roots and the stems of red beetroot (Beta vulgaris $L$. var. conditiva). Along with this, there is a lack of information on the chemical composition and biological activity of seeds of this species. The purpose of our research was to study the chemical composition of Beta vulgaris seeds and to assess the cytotoxic activity. The research objects: $\mathrm{CO}_{2}$ extracts of beetroot seeds: Thick $\mathrm{POCO}_{2}$ (1), liquid $\mathrm{POCO}_{2}$ (2) and liquid alcohol extract $\mathrm{POC}_{2} \mathrm{H}_{5}$. Determination of the component composition of the extract was performed on the gas chromatograph Clarus 580 (PerkinElmer) with the mass spectrometric detector Clarus-SQ. To determine the cytotoxic activity, the marine crustaceans Artemia salina were taken. Based on the results of the analysis of the chemical composition of the thick $\mathrm{CO}_{2}$-extract, 25 compounds were identified and the liquid $\mathrm{CO}_{2}$-extract-11 components were identified. The dominant compounds in both extracts are phenol and creosol. The results of determining the cytotoxic activity allow determining that liquid $\mathrm{CO}_{2}$ extract of beetroot seeds $\mathrm{POC}_{2} \mathrm{H}_{5}$ at a concentration of $10 \mathrm{mg} / \mathrm{mL}$ exhibits cytotoxicity (68\%) and does not exhibit activity at concentrations of 5 and 1 $\mathrm{mg} / \mathrm{mL}$; thick $\mathrm{CO}_{2}$ beetroot seed extract $\mathrm{POCO}_{2}$ (1) at all tested concentrations does not exhibit cytotoxicity; liquid alcohol extract of beetroot seeds at all tested concentrations does not exhibit cytotoxicity.
\end{abstract}

Keywords: Carbon Dioxide, Seeds Alcohol Extract, Cytotoxicity, Beta vulgaris, Component Composition, Biological Activity

\section{Introduction}

Since ancient times, plants have been used by folk medicine for the treatment of various ailments (Kukovyakina et al., 2019). With the development of technology, people have learned to identify various active substances to develop new medicines with improved properties and expand the range of efficient and safe preparations for the treatment and prevention of a number of diseases in humans and animals.

To combat the negative influence of the environment, plants use a multicomponent defence system, including a hypersensitivity reaction, strengthening of protective barriers with the use of cell wall components and activation of the production of protective proteins and antimicrobial peptides (Goyal and Mattoo, 2014). Plants of the family Amaranthaceae (Chenopodiaceae), which have long been used both as a food product and as medicinal plants, are no exception (Clifford et al., 2015; Asgary et al., 2016).

Modern studies of representatives of this family have made it possible to discover medicinal properties in plants that were used previously only as food. Thus, in the leaves of Beta vulgaris L, the protein Beetin 27 (BE27), which inactivates the Ribosome (RIP), was found. Beetin 27 is supposed to be an antiviral protein induced by viruses and 
signalling compounds such as hydrogen peroxide and salicylic acid. Its role as a protective protein is explained by its activity of the RNA polynucleotide: Adenosine glycosidase (Iglesias et al., 2005; 2015).

In vitro experiments have shown the inhibitory effect of Beta vulgaris root extract on the induction of the early antigen of the Epstein-Barr Virus (EBV-EA). Evaluation of the antitumor stimulating activity in vivo against bio samples of skin and lungs of mice also revealed a significant inhibitory effect of root extract of beetroot (Kapadia et al., 1996).

Aqueous extracts from Beta vulgaris root vegetables have shown antioxidant and antimicrobial activity in the experiments in vitro (Čanadanović-Brunet et al., 2011). Many medicinal properties are due to betalains and phenols found in the roots and the stems of red beetroot (Beta vulgaris L. var. conditiva) (Clements et al., 2014; Ben Haj Koubaier et al., 2014; Barlow et al., 2018). Despite the fact that the composition and properties of leaves and underground organs of Beta vulgaris are actively studied, there is a lack of information on the chemical composition and biological activity of seeds of this species.

We carried out preliminary studies with the seeds of Beta vulgaris, which showed the protective effect of aqueous extracts in the experiment in vivo (Konkabayeva et al., 2020).

In connection with the above, the purpose of our research was to study the chemical composition of Beta vulgaris seeds and to assess the cytotoxic activity.

\section{Materials and Methods}

\section{Research Objects}

$\mathrm{CO}_{2}$ extracts of beetroot seeds: Thick $\mathrm{POCO}_{2}$ (1), liquid $\mathrm{POCO}_{2}$ (2) and liquid alcohol extract $\mathrm{POC}_{2} \mathrm{H}_{5}$.

$\mathrm{CO}_{2}$-extracts were prepared on a $\mathrm{CO}_{2}$-extractor from air-dry seeds at a pressure of 69-76 atm and a temperature of $18-21^{\circ} \mathrm{C}$ (Sisengalieva et al., 2015).

\section{Determination by Gas Chromatography-Mass Spectrometry Method}

The determination was carried out by gas chromatography-mass spectrometry on the gas chromatograph Clarus 580 (PerkinElmer). The detector was a mass spectrometric detector Clarus-SQ 8 with a NIST base of 300,000 compounds (the table shows the Kovats indices on a semi-polar column).

\section{Method of Determining the Component Composition}

Determination of the component composition of the extract was carried out on a gas chromatograph Clarus 580 (PerkinElmer) with a mass spectrometric detector Clarus-SQ 8. The sensitivity of the device is determined by the peak signal-to-noise ratio and is 800:1 (in reality, 2000:1).
Chromatographic conditions: capillary column Restek®-5Sil MS $0.25 \mathrm{~mm} \times 30 \mathrm{~m} \times 0.25 \mu \mathrm{m}$, sample volume: $1.0 \mu \mathrm{L}$, carrier gas: He; flow rate of carrier gas: 1 $\mathrm{mL} / \mathrm{min}$, flow division $1: 25$, $\mathrm{t}$ of the column: $40^{\circ} \mathrm{C}$, temperature rising of $2^{\circ} \mathrm{C} / \mathrm{min}$ up to $280^{\circ} \mathrm{C}$, $\mathrm{t}$ of evaporator $-280^{\circ} \mathrm{C}$, mass spectrometric detector: $\mathrm{t}-240^{\circ} \mathrm{C}, \mathrm{EI}+=70 \mathrm{eB}$, scanning time: from 4 to $120 \mathrm{~min}$, ion scanning mode: 39 $500 \mathrm{~m} / \mathrm{z}$. The percentage of components was calculated automatically based on the peak areas of the total ion chromatogram. The components were identified by mass spectra and retention times using the NIST library and comparing with the retention indices of normal alkanes.

\section{Study of Cytotoxic Activity}

The study of the cytotoxic activity of $\mathrm{CO}_{2}$-extracts of beetroot seeds (thick $\mathrm{POCO}_{2}$ (1) and liquid $\mathrm{POCO}_{2}(2)$, liquid alcohol extract $\mathrm{POC}_{2} \mathrm{H}_{5}$ ) was conducted in the laboratory of the Institute of Applied Chemistry at L.N. Gumilyov Eurasian National University, according to the standard method (Terekhova, 2011).

To determine the cytotoxic activity, the marine crustaceans Artemia salina were taken. The technique is based on establishing the difference between the number of dead Artemia larvae in the analyzed sample (experiment) and water that does not contain toxic substances (control). The criterion for acute lethal toxicity of a solution of a substance is the death of $50 \%$ of the larvae and more in the experiment as compared with the control.

Dilution was made at the rate of $1 \mathrm{mg}$ of substance per $1 \mathrm{~mL}$ of solvent. Each sample was tested in three parallel runs. It was carried out at a temperature of $20 \pm 2{ }^{\circ} \mathrm{C}$, at natural light period. The salinity of the control artificial water was 8.0-8.5 (pH). During the biotesting, Artemia larvae were up to 1-day old. The stocking density of larvae is 20-40 specimens per test tube.

\section{Results}

Based on the results of the analysis of the chemical composition of the thick $\mathrm{CO}_{2}$-extract, 25 compounds were identified and the liquid extract -11 components were identified (Table 1, 2 and Fig. 1, 2).

The dominant components in both extracts are phenol and creosol. The first sample contains phenol $-0.7 \%$, cresol$0.5 \%$ of all volatile substances. The second sample contains phenol $-0.4 \%$, cresol $-0.3 \%$ of all volatile substances.

\section{Cytotoxic Activity}

We studied the cytotoxic activity by the method of survival rate of the marine crustacean Artemia salina. The test flask was filled with artificial seawater and eggs of Artemia salina were added. Artemia salina. They were kept under a soft air supply for 3 days until the crustaceans hatched from their eggs. 
Table 1: Component composition of thick $\mathrm{CO}_{2}$-extract of beetroot seeds (sample 1)

\begin{tabular}{|c|c|c|c|c|}
\hline & RI lit & RII & Component & Area $\%$ \\
\hline & $859 \pm 6$ & 851 & 2-Furanmethanol & 0.3 \\
\hline & $918 \pm 3$ & 910 & 2(5H)-Furanone & 0.3 \\
\hline & $980 \pm 4$ & 980 & Phenol & 0.7 \\
\hline & $1013 \mathrm{iu}$ & 999 & 2-Hydroxy-gamma-butyrolactone & 1.1 \\
\hline & $1043 \pm 0$ & 1034 & 1,2-Cyclopentanedione, 3-methyl- & 1.8 \\
\hline & \multirow[t]{3}{*}{$1090 \pm 3$} & 1078 & Phenol, 2-methoxy- & 1.8 \\
\hline & & & Unknown 1 & 1.0 \\
\hline & & & Unknown 2 & 6.3 \\
\hline & $1110 \pm 6$ & 1118 & Maltol & 0.4 \\
\hline & $1091 \pm 17$ & 1123 & 2-Cyclopenten-1-one, 3-ethyl-2-hydroxy- & 0.4 \\
\hline & $1169 \pm 3$ & 1164 & Phenol, 4-ethyl- & 0.4 \\
\hline & $1193 \pm 3$ & 1178 & Creosol & 0.5 \\
\hline & $1129 \mathrm{iu}$ & 1192 & 5-Oxotetrahydrofuran-2-carboxylic acid, ethyl ester & 1.0 \\
\hline & $1205 \pm 5$ & 1201 & Catechol & 1.8 \\
\hline & \multirow[t]{2}{*}{$1207 \pm 8$} & 1209 & 1,4:3,6-Dianhydro-à-d-glucopyranose & 1.9 \\
\hline & & 1218 & Unknown 3 & 0.8 \\
\hline & $1268 \pm 4$ & 1247 & Pyrocatechol, 3-methoxy- & 0.3 \\
\hline & $1282 \pm 4$ & 1264 & Phenol, 4-ethyl-2-methoxy- & 0.2 \\
\hline & $1241 \pm \mathrm{N} / \mathrm{A}$ & 1288 & Hydroquinone & 0.5 \\
\hline & $1355 \pm 5$ & 1342 & Phenol, 2,6-dimethoxy- & 1.4 \\
\hline & \multirow[t]{2}{*}{$1404 \pm 7$} & 1389 & Vanillin & 0.4 \\
\hline & & & Unknown 4 & 1.0 \\
\hline & \multirow[t]{2}{*}{$1534 \pm 5$} & 1508 & 2-Propanone, 1-(4-hydroxy-3-methoxyphenyl)- & 4.1 \\
\hline & & & Unknown 5 & 10.7 \\
\hline & $1968 \pm 7$ & 1970 & n-Hexadecanoic acid & 1.4 \\
\hline Total & & & & 40.5 \\
\hline
\end{tabular}

Table 2: Component composition of liquid $\mathrm{CO}_{2}$-extract of beetroot seeds (sample 2)

\begin{tabular}{llll}
\hline RI lit & RII & Component & Area $\%$ \\
\hline $980 \pm 4$ & 982 & Phenol & 0.4 \\
$1090 \pm 3$ & 1080 & Phenol, 2-methoxy- & 1.0 \\
1029 iu & 1095 & 1H-Pyrrole, 2,5-dihydro-1-nitroso- & 0.4 \\
& & Unknown 1 & 0.6 \\
$1169 \pm 3$ & 1165 & Phenol, 4-ethyl- & 0.6 \\
$1193 \pm 3$ & 1179 & Creosol & 0.3 \\
$1207 \pm 8$ & 1209 & $1,4: 3,6$-Dianhydro- $\alpha$-d-glucopyranose & 0.2 \\
$1282 \pm 4$ & 1265 & Phenol, 4-ethyl-2-methoxy- & 0.4 \\
$1355 \pm 5$ & 1343 & Phenol, 2,6-dimethoxy- & 0.3 \\
& & Unknown 2 & 0.3 \\
& & Unknown 3 & 1.0 \\
\hline
\end{tabular}

Table 3: $\mathrm{CO}_{2}$ extract of beetroot seeds $\mathrm{POC}_{2} \mathrm{H}_{5}$, (liquid), $10 \mathrm{mg} / \mathrm{mL}$

\begin{tabular}{|c|c|c|c|c|c|c|c|c|c|}
\hline \multirow[b]{2}{*}{ Parallel } & \multicolumn{2}{|c|}{$\begin{array}{l}\text { Number of larvae } \\
\text { in the control }\end{array}$} & \multicolumn{3}{|c|}{ Number of larvae in the sample } & \multirow{2}{*}{$\begin{array}{l}\% \text { of surviving } \\
\text { larvae in } \\
\text { the control }\end{array}$} & \multirow{2}{*}{$\begin{array}{l}\% \text { of surviving } \\
\text { larvae in } \\
\text { the sample }\end{array}$} & \multirow{2}{*}{$\begin{array}{l}\text { Mortality } \\
\text { rate, A, \% }\end{array}$} & \multirow{2}{*}{$\begin{array}{l}\text { Presence of } \\
\text { neurotoxicity, \% }\end{array}$} \\
\hline & Survivor & Dead & Survivor & Dead & Par. & & & & \\
\hline 1 & 25 & 2 & 6 & 14 & 0 & 96 & 28 & 68 & 0 \\
\hline 2 & 24 & 0 & 5 & 18 & 0 & & & & \\
\hline 3 & 23 & 0 & 7 & 16 & 0 & & & & \\
\hline Average & 24 & 1 & 6 & 16 & 0 & & & & \\
\hline
\end{tabular}

Actinomycin D or staurosporine was used as a referential preparation. Samples were tested at concentrations of 10,5 and $1 \mathrm{mg} / \mathrm{mL}$. The results of studies of cytotoxic activity for the liquid extract are presented in Table 3-5.

\section{Discussion}

Based on the performed experiment, it can be assumed that liquid $\mathrm{CO}_{2}$ extract of beetroot seeds $\mathrm{POC}_{2} \mathrm{H}_{5}$ at a concentration of $10 \mathrm{mg} / \mathrm{mL}$ exhibits 
cytotoxicity $(68 \%)$ and does not exhibit activity at concentrations of 5 and $1 \mathrm{mg} / \mathrm{mL}$.

The results of the study of the cytotoxic activity of the thick $\mathrm{CO}_{2}$ extract of beetroot seeds $\mathrm{POCO}_{2}(1)$ are shown in Tables 6-8.
Based on the experiment performed, it can be assumed that the thick $\mathrm{CO}_{2}$ extract of beetroot seeds $\mathrm{POCO}_{2}$ (1) does not exhibit cytotoxicity at all tested concentrations.

The results of the study of the cytotoxic activity of the liquid alcohol extract of beet seeds are presented in Tables 9-11.

Table 4: $\mathrm{CO}_{2}$ extract of beetroot seeds $\mathrm{POC}_{2} \mathrm{H}_{5}$, (liquid), $5 \mathrm{mg} / \mathrm{mL}$

\begin{tabular}{|c|c|c|c|c|c|c|c|c|c|}
\hline \multirow[b]{2}{*}{ Parallel } & \multicolumn{2}{|c|}{$\begin{array}{l}\text { Number of larvae } \\
\text { in the control }\end{array}$} & \multicolumn{3}{|c|}{ Number of larvae in the sample } & \multirow{2}{*}{$\begin{array}{l}\% \text { of surviving } \\
\text { larvae in } \\
\text { the control }\end{array}$} & \multirow{2}{*}{$\begin{array}{l}\% \text { of surviving } \\
\text { larvae in } \\
\text { the sample }\end{array}$} & \multirow{2}{*}{$\begin{array}{l}\text { Mortality } \\
\text { rate, A, \% }\end{array}$} & \multirow{2}{*}{$\begin{array}{l}\text { Presence of } \\
\text { neurotoxicity, } \%\end{array}$} \\
\hline & Survivor & Dead & Survivor & Dead & Par. & & & & \\
\hline 1 & 25 & 2 & 10 & 10 & 0 & 96 & 48 & 48 & 0 \\
\hline 2 & 24 & 0 & 9 & 14 & 0 & & & & \\
\hline 3 & 23 & 0 & 10 & 10 & 0 & & & & \\
\hline Average & 24 & 1 & 10 & 11 & 0 & & & & \\
\hline
\end{tabular}

Table 5: $\mathrm{CO}_{2}$ extract of beetroot seeds $\mathrm{POC}_{2} \mathrm{H}_{5}$, (liquid), $1 \mathrm{mg} / \mathrm{mL}$

\begin{tabular}{|c|c|c|c|c|c|c|c|c|c|}
\hline \multirow[b]{2}{*}{ Parallel } & \multicolumn{2}{|c|}{$\begin{array}{l}\text { Number of larvae } \\
\text { in the control }\end{array}$} & \multicolumn{3}{|c|}{ Number of larvae in the sample } & \multirow{2}{*}{$\begin{array}{l}\% \text { of surviving } \\
\text { larvae in } \\
\text { the control }\end{array}$} & \multirow{2}{*}{$\begin{array}{l}\% \text { of surviving } \\
\text { larvae in } \\
\text { the sample }\end{array}$} & \multirow{2}{*}{$\begin{array}{l}\text { Mortality } \\
\text { rate, A, \% }\end{array}$} & \multirow{2}{*}{$\begin{array}{l}\text { Presence of } \\
\text { neurotoxicity, \% }\end{array}$} \\
\hline & Survivor & Dead & Survivor & Dead & Par. & & & & \\
\hline 1 & 25 & 2 & 23 & 0 & 0 & 96 & 96 & 0 & 0 \\
\hline 2 & 24 & 0 & 22 & 0 & 0 & & & & \\
\hline 3 & 23 & 0 & 22 & 0 & 0 & & & & \\
\hline Average & 24 & 1 & 22 & 0 & 0 & & & & \\
\hline
\end{tabular}

Table 6: $\mathrm{CO}_{2}$ extract of beetroot seeds $\mathrm{POCO}_{2}$ (1), (thick), $10 \mathrm{mg} / \mathrm{mL}$

\begin{tabular}{|c|c|c|c|c|c|c|c|c|c|}
\hline \multirow[b]{2}{*}{ Parallel } & \multicolumn{2}{|c|}{$\begin{array}{l}\text { Number of larvae } \\
\text { in the control }\end{array}$} & \multicolumn{3}{|c|}{ Number of larvae in the sample } & \multirow{2}{*}{$\begin{array}{l}\% \text { of surviving } \\
\text { larvae in } \\
\text { the control }\end{array}$} & \multirow{2}{*}{$\begin{array}{l}\% \text { of surviving } \\
\text { larvae in } \\
\text { the sample }\end{array}$} & \multirow{2}{*}{$\begin{array}{l}\text { Mortality } \\
\text { rate, A, \% }\end{array}$} & \multirow{2}{*}{$\begin{array}{l}\text { Presence of } \\
\text { neurotoxicity, } \%\end{array}$} \\
\hline & Survivor & Dead & Survivor & Dead & Par. & & & & \\
\hline 1 & 25 & 2 & 17 & 3 & 0 & 96 & 86 & 10 & 0 \\
\hline 2 & 24 & 0 & 18 & 3 & 0 & & & & \\
\hline 3 & 23 & 0 & 18 & 4 & 0 & & & & \\
\hline Average & 24 & 1 & 18 & 3 & 0 & & & & \\
\hline
\end{tabular}

Table 7: $\mathrm{CO}_{2}$ extract of beetroot seeds $\mathrm{POCO}_{2}$ (1), (thick), $5 \mathrm{mg} / \mathrm{mL}$

\begin{tabular}{|c|c|c|c|c|c|c|c|c|c|}
\hline \multirow[b]{2}{*}{ Parallel } & \multicolumn{2}{|c|}{$\begin{array}{l}\text { Number of larvae } \\
\text { in the control }\end{array}$} & \multicolumn{3}{|c|}{ Number of larvae in the sample } & \multirow{2}{*}{$\begin{array}{l}\% \text { of surviving } \\
\text { larvae in } \\
\text { the control }\end{array}$} & \multirow{2}{*}{$\begin{array}{l}\% \text { of surviving } \\
\text { larvae in } \\
\text { the sample }\end{array}$} & \multirow{2}{*}{$\begin{array}{l}\text { Mortality } \\
\text { rate, A, \% }\end{array}$} & \multirow{2}{*}{$\begin{array}{l}\text { Presence of } \\
\text { neurotoxicity, \% }\end{array}$} \\
\hline & Survivor & Dead & Survivor & Dead & Par. & & & & \\
\hline 1 & 25 & 2 & 20 & 3 & 0 & 96 & 88 & 8 & 0 \\
\hline 2 & 24 & 0 & 21 & 3 & 0 & & & & \\
\hline 3 & 23 & 0 & 24 & 2 & 0 & & & & \\
\hline Average & 24 & 1 & 22 & 3 & 0 & & & & \\
\hline
\end{tabular}

Table 8: $\mathrm{CO}_{2}$ extract of beetroot seeds $\mathrm{POCO}_{2}$ (1), (thick), $1 \mathrm{mg} / \mathrm{mL}$

\begin{tabular}{|c|c|c|c|c|c|c|c|c|c|}
\hline \multirow[b]{2}{*}{ Parallel } & \multicolumn{2}{|c|}{$\begin{array}{l}\text { Number of larvae } \\
\text { in the control }\end{array}$} & \multicolumn{3}{|c|}{ Number of larvae in the sample } & \multirow{2}{*}{$\begin{array}{l}\% \text { of surviving } \\
\text { larvae in } \\
\text { the control }\end{array}$} & \multirow{2}{*}{$\begin{array}{l}\% \text { of surviving } \\
\text { larvae in } \\
\text { the sample }\end{array}$} & \multirow{2}{*}{$\begin{array}{l}\text { Mortality } \\
\text { rate, A, \% }\end{array}$} & \multirow{2}{*}{$\begin{array}{l}\text { Presence of } \\
\text { neurotoxicity, \% }\end{array}$} \\
\hline & Survivor & Dead & Survivor & Dead & Par. & & & & \\
\hline 1 & 25 & 2 & 19 & 2 & 0 & 96 & 96 & 0 & 0 \\
\hline 2 & 24 & 0 & 20 & 1 & 0 & & & & \\
\hline 3 & 23 & 0 & 24 & 1 & 0 & & & & \\
\hline Average & 24 & 1 & 21 & 1 & 0 & & & & \\
\hline
\end{tabular}


Table 9: Liquid alcohol beetroot seed extract, $10 \mathrm{mg} / \mathrm{mL}$

\begin{tabular}{|c|c|c|c|c|c|c|c|c|c|}
\hline \multirow[b]{2}{*}{ Parallel } & \multicolumn{2}{|c|}{$\begin{array}{l}\text { Number of larvae } \\
\text { in the control }\end{array}$} & \multicolumn{3}{|c|}{ Number of larvae in the sample } & \multirow{2}{*}{$\begin{array}{l}\% \text { of surviving } \\
\text { larvae in } \\
\text { the control }\end{array}$} & \multirow{2}{*}{$\begin{array}{l}\% \text { of surviving } \\
\text { larvae in } \\
\text { the sample }\end{array}$} & \multirow{2}{*}{$\begin{array}{l}\text { Mortality } \\
\text { rate, A, \% }\end{array}$} & \multirow{2}{*}{$\begin{array}{l}\text { Presence of } \\
\text { neurotoxicity, \% }\end{array}$} \\
\hline & Survivor & Dead & Survivor & Dead & Par. & & & & \\
\hline 1 & 25 & 2 & 22 & 7 & 0 & 96 & 75 & 21 & 0 \\
\hline 2 & 24 & 0 & 17 & 5 & 0 & & & & \\
\hline 3 & 23 & 0 & 15 & 7 & 0 & & & & \\
\hline Average & 24 & 1 & 18 & 6 & 0 & & & & \\
\hline
\end{tabular}

Table 10: Liquid alcohol beetroot seed extract, $5 \mathrm{mg} / \mathrm{mL}$

\begin{tabular}{|c|c|c|c|c|c|c|c|c|c|}
\hline \multirow[b]{2}{*}{ Parallel } & \multicolumn{2}{|c|}{$\begin{array}{l}\text { Number of larvae } \\
\text { in the control }\end{array}$} & \multicolumn{3}{|c|}{ Number of larvae in the sample } & \multirow{2}{*}{$\begin{array}{l}\% \text { of surviving } \\
\text { larvae in } \\
\text { the control }\end{array}$} & \multirow{2}{*}{$\begin{array}{l}\% \text { of surviving } \\
\text { larvae in } \\
\text { the sample }\end{array}$} & \multirow{2}{*}{$\begin{array}{l}\text { Mortality } \\
\text { rate, A, \% }\end{array}$} & \multirow{2}{*}{$\begin{array}{l}\text { Presence of } \\
\text { neurotoxicity, } \%\end{array}$} \\
\hline & Survivor & Dead & Survivor & Dead & Par. & & & & \\
\hline 1 & 25 & 2 & 20 & 2 & 0 & 96 & 87 & 9 & 0 \\
\hline 2 & 24 & 0 & 18 & 4 & 0 & & & & \\
\hline 3 & 23 & 0 & 18 & 4 & 0 & & & & \\
\hline Average & 24 & 1 & 19 & 3 & 0 & & & & \\
\hline
\end{tabular}

Table 11: Liquid alcohol beetroot seed extract, $1 \mathrm{mg} / \mathrm{mL}$

\begin{tabular}{|c|c|c|c|c|c|c|c|c|c|}
\hline \multirow[b]{2}{*}{ Parallel } & \multicolumn{2}{|c|}{$\begin{array}{l}\text { Number of larvae } \\
\text { in the control }\end{array}$} & \multicolumn{3}{|c|}{ Number of larvae in the sample } & \multirow{2}{*}{$\begin{array}{l}\% \text { of surviving } \\
\text { larvae in } \\
\text { the control }\end{array}$} & \multirow{2}{*}{$\begin{array}{l}\% \text { of surviving } \\
\text { larvae in } \\
\text { the sample }\end{array}$} & \multirow{2}{*}{$\begin{array}{l}\text { Mortality } \\
\text { rate, A, \% }\end{array}$} & \multirow{2}{*}{$\begin{array}{l}\begin{array}{l}\text { Presence of } \\
\text { neurotoxicity, \% }\end{array} \\
\end{array}$} \\
\hline & Survivor & Dead & Survivor & Dead & Par. & & & & \\
\hline 1 & 25 & 2 & 24 & 1 & 0 & 96 & 92 & 4 & 0 \\
\hline 2 & 24 & 0 & 23 & 3 & 0 & & & & \\
\hline 3 & 23 & 0 & 24 & 2 & 0 & & & & \\
\hline Average & 24 & 1 & 24 & 2 & 0 & & & & \\
\hline
\end{tabular}

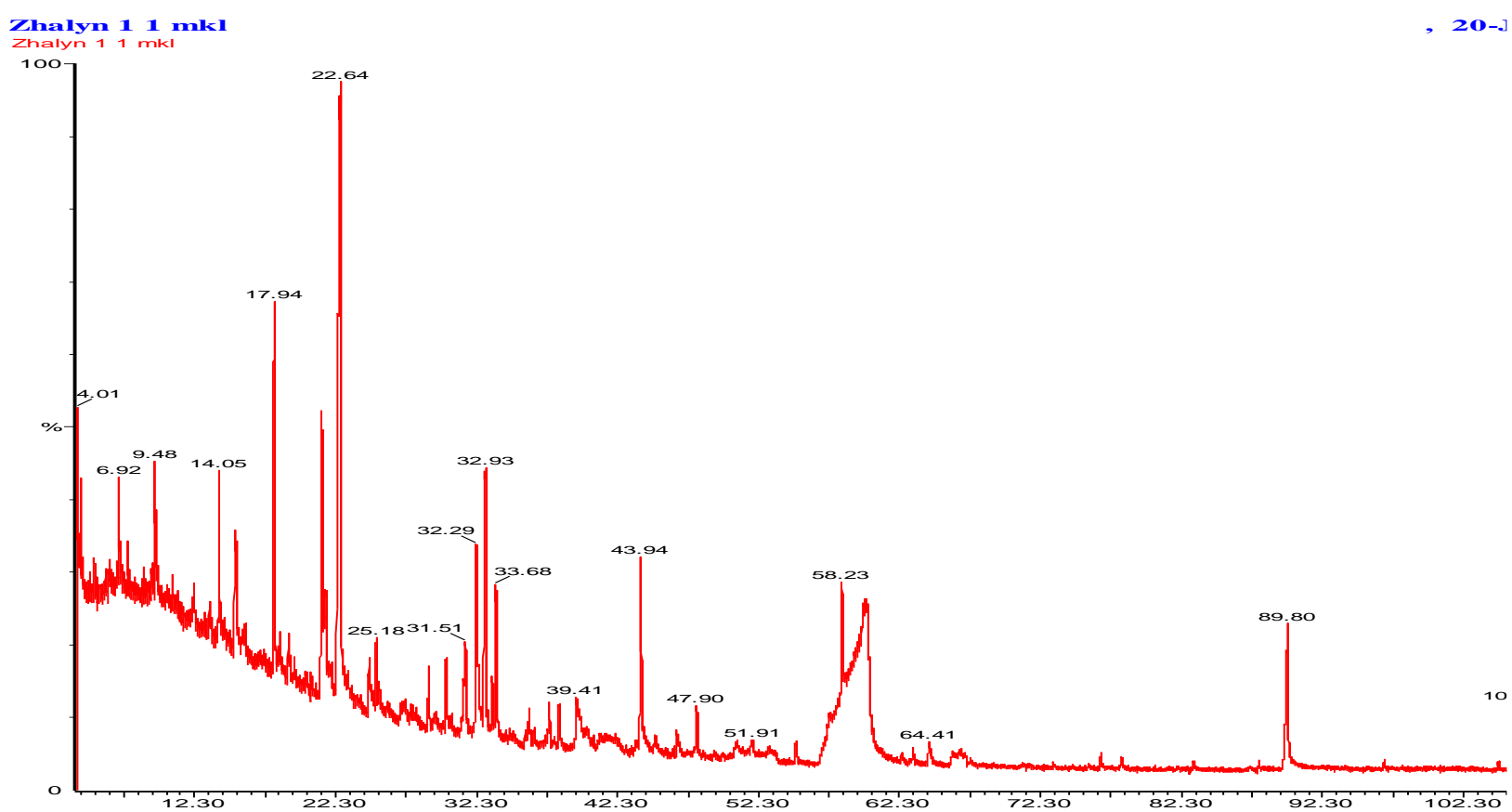

Fig. 1: Chromatogram of thick $\mathrm{CO}_{2}$-extract of beetroot seeds (sample 1) 


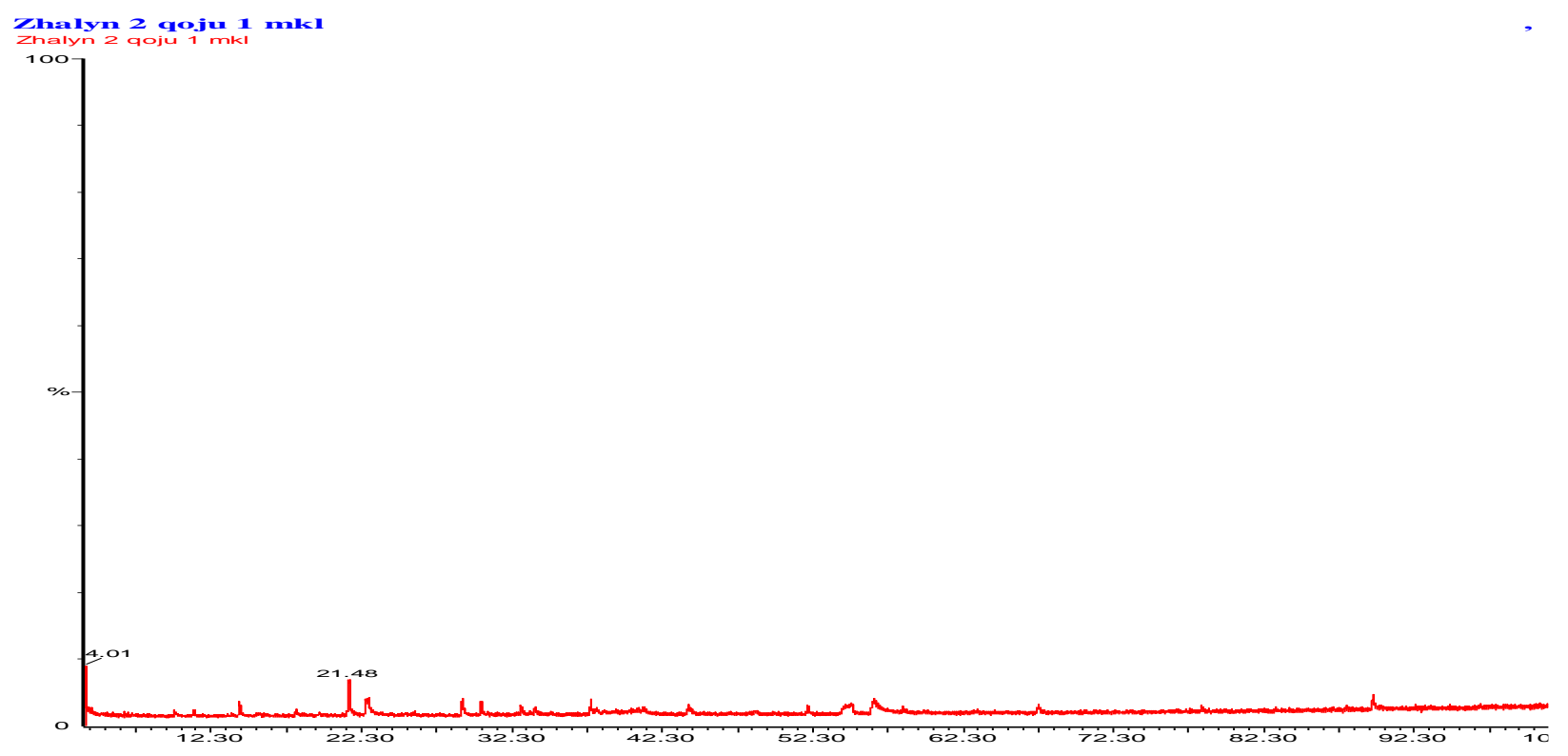

Fig. 2: Chromatogram of liquid $\mathrm{CO}_{2}$-extract of beetroot seeds (sample 2)

Based on the experiment performed, it can be assumed that the liquid alcohol extract of beetroot seeds at all tested concentrations does not exhibit cytotoxicity.

\section{Conclusion}

Thus, a study of the component composition of $\mathrm{CO}_{2-}$ extracts from common beetroot seeds was carried out, according to the results of which 25 (for the thick extract) and 11 (for the liquid extract) components were identified. The dominant components are phenol and cresol.

The results of determining the cytotoxic activity allow determining that liquid $\mathrm{CO}_{2}$ extract of beetroot seeds $\mathrm{POC}_{2} \mathrm{H}_{5}$ at a concentration of $10 \mathrm{mg} / \mathrm{mL}$ exhibits cytotoxicity $(68 \%)$ and does not exhibit activity at concentrations of 5 and $1 \mathrm{mg} / \mathrm{mL}$; thick $\mathrm{CO}_{2}$ beetroot seed extract $\mathrm{POCO}_{2}$ (1) does not exhibit cytotoxicity at all tested concentrations; liquid alcohol extract of beetroot seeds at all tested concentrations does not exhibit cytotoxicity.

\section{Acknowledgement}

The work was carried out within the framework of an internal grant from E.A. Buketov Karaganda University No. 219-B-19 "Study and evaluation of the medicinal properties of seeds of the plant Beta vulgaris of the family Amaranthaceae in the experiment".

\section{Author's Contributions}

Aiman Konkabayeva: Concept, manuscript writing, critical revision of manuscript, final approval.
Yerlan Suleimen: Concept, manuscript writing, data collection, analysis, final approval.

Margarita Ishmuratova: Analysis, manuscript writing, data interpretation, final approval.

Gulmira Tykezhanova: Data interpretation, manuscript writing, critical revision of manuscript, final approval.

Aidana Yerubay: Analysis, data collection, data interpretation, final approval.

\section{Ethics}

This article is original and contains unpublished material. The corresponding author confirms that all of the other authors have read and approved the manuscript and no ethical issues involved.

\section{References}

Asgary, S., Afshani, M. R., Sahebkar, A., Keshvari, M., Taheri, M., Jahanian, E., ... \& Sarrafzadegan, N. (2016). Improvement of hypertension, endothelial function and systemic inflammation following shortterm supplementation with red beet (Beta vulgaris L.) juice: a randomized crossover pilot study. Journal of Human Hypertension, 30(10), 627-632. https://doi.org/10.1038/jhh.2016.34

Barlow, M. J., Elia, A., Shannon, O. M., Zacharogianni, A., \& Lodin-Sundstrom, A. (2018). The effect of a dietary nitrate supplementation in the form of a single shot of beetroot juice on static and dynamic apnea performance. International Journal of Sport Nutrition and Exercise Metabolism, 28(5), 497-501. https://doi.org/10.1123/ijsnem.2017-0300 
Ben Haj Koubaier, H., Snoussi, A., Essaidi, I., Chaabouni, M. M., Thonart, P., \& Bouzouita, N. (2014). Betalain and phenolic compositions, antioxidant activity of Tunisian red beet (Beta vulgaris L. conditiva) roots and stems extracts. International Journal of food Properties, 17(9), 1934-1945. https://doi.org/10.1080/10942912.2013.772196

Čanadanović-Brunet, J. M., Savatović, S. S., Ćetković, G. S., Vulić, J. J., Djilas, S. M., Markov, S. L., \& Cvetković, D. D. (2011). Antioxidant and antimicrobial activities of beet root pomace extracts. Czech Journal of Food Sciences, 29(6), 575-585. https://doi.org/10.17221/210/2010-CJFS

Clements, W. T., Lee, S. R., \& Bloomer, R. J. (2014). Nitrate ingestion: a review of the health and physical performance effects. Nutrients, 6(11), 5224-5264. https://doi.org/10.3390/nu6115224

Goyal, R. K., \& Mattoo, A. K. (2014). Multitasking antimicrobial peptides in plant development and host defense against biotic/abiotic stress. Plant Science, 228, 135-149. https://doi.org/10.1016/j.plantsci.2014.05.012

Iglesias, R., Citores, L., Di Maro, A., \& Ferreras, J. M. (2015). Biological activities of the antiviral protein BE27 from sugar beet (Beta vulgaris L.). Planta, 241(2), 421-433. https://doi.org/10.1007/s00425014-2191-2

Iglesias, R., Pérez, Y., de Torre, C., Ferreras, J. M., Antolín, P., Jiménez, P., ... \& Girbés, T. (2005). Molecular characterization and systemic induction of single-chain ribosome-inactivating proteins (RIPs) in sugar beet (Beta vulgaris) leaves. Journal of Experimental Botany, 56(416), 1675-1684. https://doi.org/10.1093/jxb/eri164
Kapadia, G. J., Tokuda, H., Konoshima, T., \& Nishino, H. (1996). Chemoprevention of lung and skin cancer by Beta vulgaris (beet) root extract. Cancer letters, 100(1-2), 211-214. https://doi.org/10.1016/03043835(95)04087-0

Clifford, T., Howatson, G., West, D. J., \& Stevenson, E. J. (2015). The potential benefits of red beetroot supplementation in health and disease. Nutrients, 7(4), 2801-2822. https://doi.org/10.3390/nu7042801

Konkabayeva, A., Tykezhanova, G., Pudov, A. M., \& Sirman, D. Y. (2020). Infusion of Beta vulgaris seeds: protective action in experiment in vivo. EurAsian Journal of Biosciences, 14(1), 323-328. http://www.ejobios.org/article/infusion-of-betavulgaris-seeds-protective-action-in-experiment-invivo-7495

Kukovyakina, N.D., E.S. Kukovyakina and S.A. Kukovyakin. (2019). The use of herbal remedies for treatment in the era of the ancient world. Vyatka Medicine Booklet, 4(64), 89-91. https://doi.org/10.24411/2220-7880-2019-10043

Sisengalieva, G. G., Suleimen, E. M., Ishmuratova, M. Y., Iskakova, Z. B., \& Van Hecke, K. (2015). Constituents of Artemisia tschernieviana and their biological activity. Chemistry of Natural Compounds, 51(3), 544-547. https://doi.org/10.1007/s10600-015-1337-1

Terekhova, V. A. (2011). Soil bioassay: Problems and approaches. Eurasian Soil Science, 44, 173-179. https://doi.org/10.1134/S1064229311020141 